\title{
Evaluation antioxidant activity and corrosion inhibition of C38 in Hydrochloric acid medium by dried lemon peels of Kenitra Marrakech cities in Morocco and Taiz town in Yemen: A Comparative study
}

\author{
Khaled $\mathrm{Abdu}^{1, *}$, Rahma Erahioui $^{2}$, Khadija Khedid ${ }^{3}$, Hefdhal deen ${ }^{4}$, Maha \\ Elhawary ${ }^{5},{\text { Abdallah } \text { Laqh }^{6} \text {, Adnane El Hamidi }}^{7}$, Ahmed Zahidi ${ }^{8}$,Ali Al emad ${ }^{9}$, and Said Ibn \\ Ahmed ${ }^{1}$
}

${ }^{1}$ Laboratoire de chimie organique, de catalyse et d'environnement.Laboratory Ibn TofailUniversity, Morocco.

${ }^{2}$ Laboratory of Agrophysiology, Biotechnology, Environment and Quality IbnTofail University BP 133 Kenitra, Morocco.

${ }^{3}$ Department of Bacteriology, National Institute of Health (NIH), 27 Avenue, IbnBatouta, P.O. Box 769, Agdal, Rabat, 11000, Morocco.

${ }^{4}$ Laboratory of Spectroscopy, Molecular Modelling, Materials, Nanomaterials, Water and Environment, CERN2D, ENSAM, Mohamed V University, Rabat, Morocco.

${ }^{5}$ Doctorate-Researchers; Faculty of Sciences Laboratory of Materials Nanotechnologies, and Environment Mohammed V-Agdal University, Morocco.

${ }^{6}$ laboratory of substances natural's and thermals espalier, Faculty of Sciences, University Mohammed V, Rabat, Morocco

${ }^{7}$ Laboratory of Materials, Nanotechnologies and Environment, Center of Science of Materials, Faculty of Sciences, University Mohammed V, and Rabat, Morocco.

${ }^{8}$ Department of Drug Sciences, Laboratory of Medicinal Chemistry, Faculty of Medicine and Pharmacy, Mohammed V University in Rabat, Morocco.

${ }^{9}$ Ministry of Education in Yemen

*00212632678673,E-mail khalidsharafedine@gmail.com

\begin{abstract}
This paper presents a comparative study about the evaluation of antioxidant activity and corrosion inhibition in Kenitra, Marrakesh and Taiz. An interesting topic, indeed polyphenols can improve or help to reduce oxidative stress in the treatment of digestive problems, weight management difficulties, diabetes, hypertension, arteriosclerosis and damage fatty tissue. Therefore, the authors deal with the measurement of polyphenol content and evaluation of the antioxidant activity of lemon peels in Kenitra, Marrakesh and Taiz.The authors performs empirical analyzes on lemon peels. The total polyphenol contents of the ethanolic extract of lemon peels were measured. It was to be 30. 23, 26. 346 and $20.961 \mathrm{mg} / \mathrm{CE} / \mathrm{g}$ in Kenitra, Marrakech, and Taiz, respectively. Moreover, the DPPH radical scavenging activity of ethanolic extract of dried lemon peels was higher than $200 \mu \mathrm{g} / \mathrm{ml}$ concentration. They were $73.47 \%$, 47.36\%, and 32.09in Kenitra, Marrakech, and Taiz, respectively. Also, the IC50 values of ethanolic extracts calculated from the percentage inhibitions at the same concentration. Inhibition (IC50) which obtained in Kenitra was $123.089 \mu \mathrm{g} / \mathrm{ml}$. It was lower compared to the ethanol extract of Marrakech and Taiz that were $197.418,276.750 \mu \mathrm{g} / \mathrm{mL}$, respectively. Therefore, the extract which is containing a high amount of phenolic is showed high
\end{abstract}


radical scavenging activity. In addition, the maximum inhibition efficiencies for $2 \mathrm{~mL} \mathrm{~L}-1$ of the inhibitor at $298 \mathrm{k}$ were $98,12 \%$ and 84,85 $\%$ in Kenitra and Taiz, respectively. These values obtained through polarization curve measurements.

\section{Introduction}

Antibiotics are widely used to treat or prevent viral and fungal pathogens. Thus, all types of antibiotics depend on its synthetic components and are used as synthetic derivatives [1]. Since penicillin was introducing into medical treatment in 1942, hundreds of antibiotics have been made to saving the lives of humans and animals from infection of pathogens. Also, antibiotics played an essential role in increasing life expectancy witnessed in the second half of the 20th century. Antibiotics also have been used in agriculture and livestock to improve food efficiency in livestock, treat infection and prevent [2]. But the overuse and misuse of antibiotics have resulted in the rapid emergence of chronic disease, which reduced its therapeutic potential against human and animal pathogens [3].

Oxidative stress occurs in an imbalance between free radicals and antioxidants in the human body. Therefore, these sources of free radicals those cause oxidative stress. They have harmful effects such as damaged fat tissue, atherosclerosis, the hardening of the blood vessels inflammatory and high blood pressure [4]. In recent years, the emphasis has shifted to protect cells and lowering oxygen concentrations to avoid oxidative stress. And that by using natural antioxidants that are already found in vegetables, fruits, grains, beverages, and other food products, because it contains crucial compoundsto treatment such as ascorbic acid, Vitamin C, Vitamin E, carotenoids flavonoid, tannins, lignin, and polyphenols [5].

Lemon peels are rich in secondary metabolites such as phenolic and flavonoids. These compounds are responsible for a variety of beneficial biological effects [6]. As well as, the compounds organic has shown good corrosion inhibitor activity, which has caused a global concern for of lives humans and the environment. These organic and inorganic inhibitors are non-dissolving, if we would add a hydrochloric acid solution to them [13,14]. So they are harmful to humans and the environment during the synthesis and application $[15,16]$.The current study focused on plants, because they contain secondary metabolites and natural organic compounds and include sulfur, nitrogen and oxygen $[17,18]$. In addition, they are non-toxic, inexpensive, and we can get benefit from the remnants of its peels [19].

\section{Materialand Methods}

\subsection{Soxhlet and Hydro distillation apparatus}

Using hydrodistillation to extract the essential oils of dried lemon peels according to the European Pharmacopoeia protocol [20].

Using a Soxhlet apparatus to extract Ethanol from dried lemon according to Lin protocol [21]. 


\subsection{The Folin-Ciocalteu}

Using of Folin-Ciocalteu to evaluate the polyphenol content of ethanol extract for dried lemon peels of Marrakech, Kenitra and Taiz according to Lister and Wilson [22].

\subsection{The 2,2'-Diphenyl- picrylhydrazyl hydrate (DPPH)}

Using of 2,2'-Diphenyl- picrylhydrazyl hydrate $(D P P H)$ detector to evaluate the free radical scavenging activity of ethanolic extract for dried lemon peels of Marrakech , Kenitra and Taiz according to Contreras-Guzman ES, Strong [23].

\subsection{Electrode and Solution}

Using an electrode and solution for corrosion test on electrodes of C38 plates of ethanol extract of dried lemon peels of kenitra and Taiz cities.

\subsection{Electrochemical measurements}

Using of potentiodynamic polarization curves and electrochemical impedance spectroscopy (EIS), which are performed in a three-electrode cell.

\section{Results and Discussion}

The results of the current study were in the yield, total Polyphenol Content, and evaluation of Antioxidant Activity of dried peels lemon of Marrakech, Kenitra and Taize.In addition, corrosion inhibition of $C 38$ in $1 M$ Hydrochloric acid by ethanolic extract of dried lemon peels of Kenitraand Taiz.

\subsection{The yield of dried lemon peel extracts}

The yield rate of the essential oils in Marrakech, essential oils in Kenitra, ethanol extract in Marrakech, ethanol extract in Kenitra , and ethanol extract in Taiz Ewere $0.31 \%$, $0.42 \%, 18.39 \%, 25.553 \%$, and $13.43 \%$ respectively In Table 1.

Table 1. The yield of essential oil and extracted Ethanol of dried lemon peel of Marrakech and Kenitra cities in Morocco and Taiz city in Yemen.

\begin{tabular}{|l|l|l|l|l|l|}
\hline EXTRACT & EO1 & EO2 & EO3 & EO4 & E05 \\
\hline$R \%$ & 0.31 & 0.42 & 18.392 & 25.553 & 13.43 \\
\hline
\end{tabular}

Key: The essential oils in Marrakech EO1, essential oils in Kenitra EO2, ethanol extract in Marrakech EO3, ethanol extract in Kenitra(EO4), and ethanol extract in Taiz EO5

\subsection{Total Polyphenol Content}

The standard curve $(\mathrm{y}=0.001 \mathrm{x}-0,001, \mathrm{r} 2=0.995)$ to determine the total polyphenols content which obtained by measuring the absorbance of the standard solution for Gallic acid and is shown in Table 2 and Fig 1. The concentrations of total polyphenols obtained were presented in (Table 3). They were expressed in $\mu g E A G / g E S$. 
Table 2.Absorbance of Gallic acid $750 \mathrm{~nm}$

\begin{tabular}{|l|l|}
\hline $\begin{array}{l}\text { Concentration } \\
(\boldsymbol{\mu} \mathbf{g} / \mathbf{m l})\end{array}$ & $\begin{array}{l}\text { Absorbance } \\
\text { at 765nm }\end{array}$ \\
\hline 10 & 0.013 \\
\hline 20 & 0.022 \\
\hline 30 & 0.032 \\
\hline 60 & 0.073 \\
\hline 70 & 0.085 \\
\hline
\end{tabular}

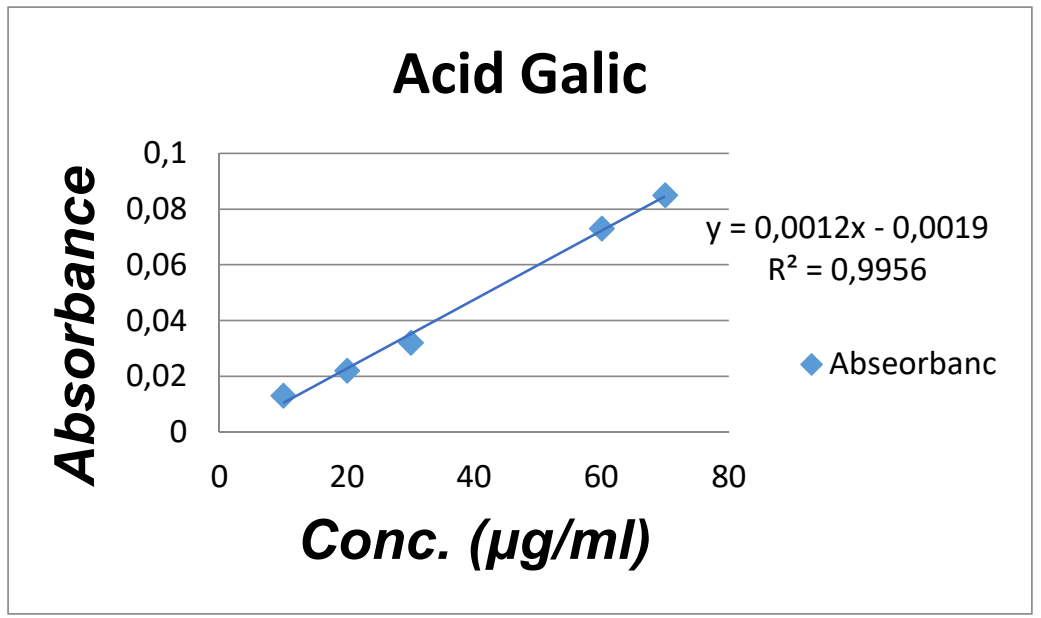

Fig.1.Calibration curve of Gallic acid standard ofTaiz.

Table 3.Determination of Polyphenol content for the ethanolic extracts of lemon peels of Marrakech ,Kenitra and Taiz

\begin{tabular}{|l|l|l|l|l|l|l|}
\hline S/E & $\begin{array}{l}\text { Sample } \\
\text { solution } \\
\mu \mathrm{g} / \mathrm{ml}\end{array}$ & $\begin{array}{l}\text { Weight of } \\
\text { dry } \\
\text { Extract } \\
\mathrm{mg} / \mathrm{ml}\end{array}$ & $\mathbf{A}^{\circ}$ & $\begin{array}{l}\text { GAEConc } \\
\text { C } \mu \mathrm{g} / \mathrm{ml}\end{array}$ & $\begin{array}{l}\text { GAE } \\
\text { Conc } \\
\text { C } \\
\mathrm{mg} / \mathrm{ml}\end{array}$ & $\begin{array}{l}\text { TPC as } \\
\text { GAE } \\
\mu \mathrm{g} / \mathrm{ml}\end{array}$ \\
\hline$K$ & 1000 & 0.001 & 0.729 & 30.23 & $\mathbf{0 . 0 3 0 2}$ & $\mathbf{3 0 . 2 3}$ \\
\hline$M$ & 1000 & 0.001 & 0.524 & 26.34 & $\mathbf{0 . 0 2 6 3}$ & 26.34 \\
\hline$T$ & 1000 & 0.001 & 0.488 & 20.96 & $\mathbf{0 . 0 2 0 9}$ & 20.96 \\
\hline
\end{tabular}

S/E: Sample/Ethanol; A ${ }^{\circ}$ : Absorbance at 765nm; K: Kenitra; M: Marrakech, T: Taiz

\subsection{Antioxidant Activity (AA)}

The table (4) and Fig (2) clarify the radical scavenging activities by using of (DPPH) which evaluated of standard ascorbic acid at different concentrations. In Table (5) and Fig (3), the radical scavenging activities were evaluated at different concentrations of extract ethanolic of dried lemon peels of Marrakech, Kenitra andTaiz. In Table 6, there are a comparison between the total phenolic content and IC50 values of ethanolic extract for the dried lemon peels of Marrakech, Kenitra andTaiz. 
Table 4.The radical scavenging activity of standard ascorbic acid

\begin{tabular}{|l|l|l|}
\hline Standard Con $\mu \mathrm{g} / \mathrm{ml}$ & Acid ascorbic & \multicolumn{1}{c|}{ SCV } \\
\hline \multicolumn{1}{|c|}{ Absorbance 517nm } \\
\hline 20 & 0,034 & 52,11 \\
\hline 40 & 0,032 & 54,92 \\
\hline 60 & 0,030 & 57,74 \\
\hline 80 & 0,029 & 59,15 \\
\hline 100 & 0,027 & 61,97 \\
\hline 160 & 0,024 & 66,19 \\
\hline 200 & 0,020 & 71,83 \\
\hline Blank & 0,071 & \\
\hline
\end{tabular}

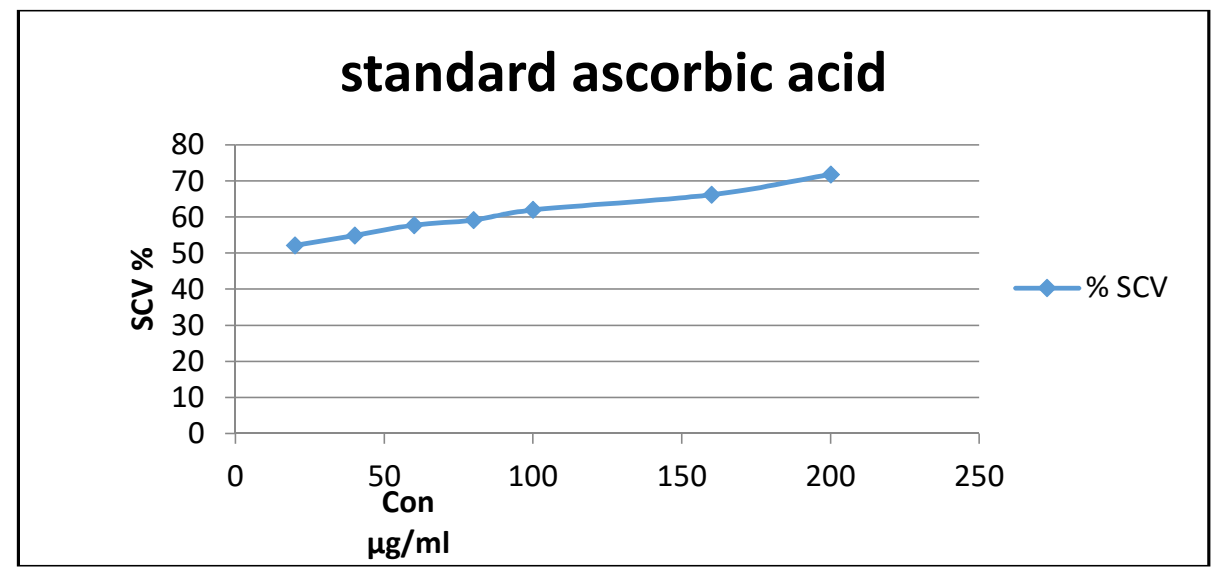

Fig. 2. Calibration curve of standard ascorbic acid.

Table 5. The radical scavenging activity of ethanolic extract of the dried lemon peel of Marrakech, Kenitra and Taiz

\begin{tabular}{|c|c|c|c|c|c|c|}
\hline $\begin{array}{l}\text { Concentra } \\
\text { tion }\end{array}$ & $\begin{array}{l}\text { Absorban } \\
\text { ce } \\
\text { moyenne }\end{array}$ & $\begin{array}{lll}\stackrel{\circ}{\circ} & S C V & K \\
E T & & \end{array}$ & $\begin{array}{l}\text { Absorban } \\
\text { ce } \\
\text { moyenne }\end{array}$ & $\begin{array}{lll}\frac{\circ}{\circ} & S C V & M \\
E T & & \end{array}$ & $\begin{array}{l}\text { Absorban } \\
\text { ce } \\
\text { moyenne }\end{array}$ & $\begin{array}{lll}\stackrel{\circ}{0} & S C V & Y \\
E T & & \end{array}$ \\
\hline 40 & 0,384 & 20,74303 & 0,255 & 12,2807 & 0,479 & 1,135191 \\
\hline 60 & 0,328 & 32,30134 & 0,263 & 18,47265 & 0,425 & 10,62951 \\
\hline 80 & 0,319 & 34,15893 & 0,354 & 23,32301 & 0,433 & 12,2807 \\
\hline 100 & 0,284 & $\begin{array}{l}41,382868 \\
9\end{array}$ & 0,3715 & $\begin{array}{l}26,934984 \\
5\end{array}$ & 0,4095 & $\begin{array}{l}15,479876 \\
2\end{array}$ \\
\hline 160 & 0,168 & $\begin{array}{l}65,325077 \\
4\end{array}$ & 0,395 & $\begin{array}{l}45,717234 \\
3\end{array}$ & 0,37 & $\begin{array}{l}23,632610 \\
9\end{array}$ \\
\hline 200 & 0,1285 & $\begin{array}{l}73,477812 \\
2\end{array}$ & 0,425 & $\begin{array}{l}47,368421 \\
1\end{array}$ & 0,329 & $\begin{array}{l}32,094943 \\
2\end{array}$ \\
\hline Blank & 0,4845 & & 0,4845 & & 0,4845 & \\
\hline
\end{tabular}

Key :

$\%$ SCV MET: percentage scavenging activity of Ethanol extract Marrakech 
$\%$ SCV KET: percentage scavenging activity of Ethanol extract kenitra

\%SCV TET: percentage scavenging activity of Ethanol extract Taiz
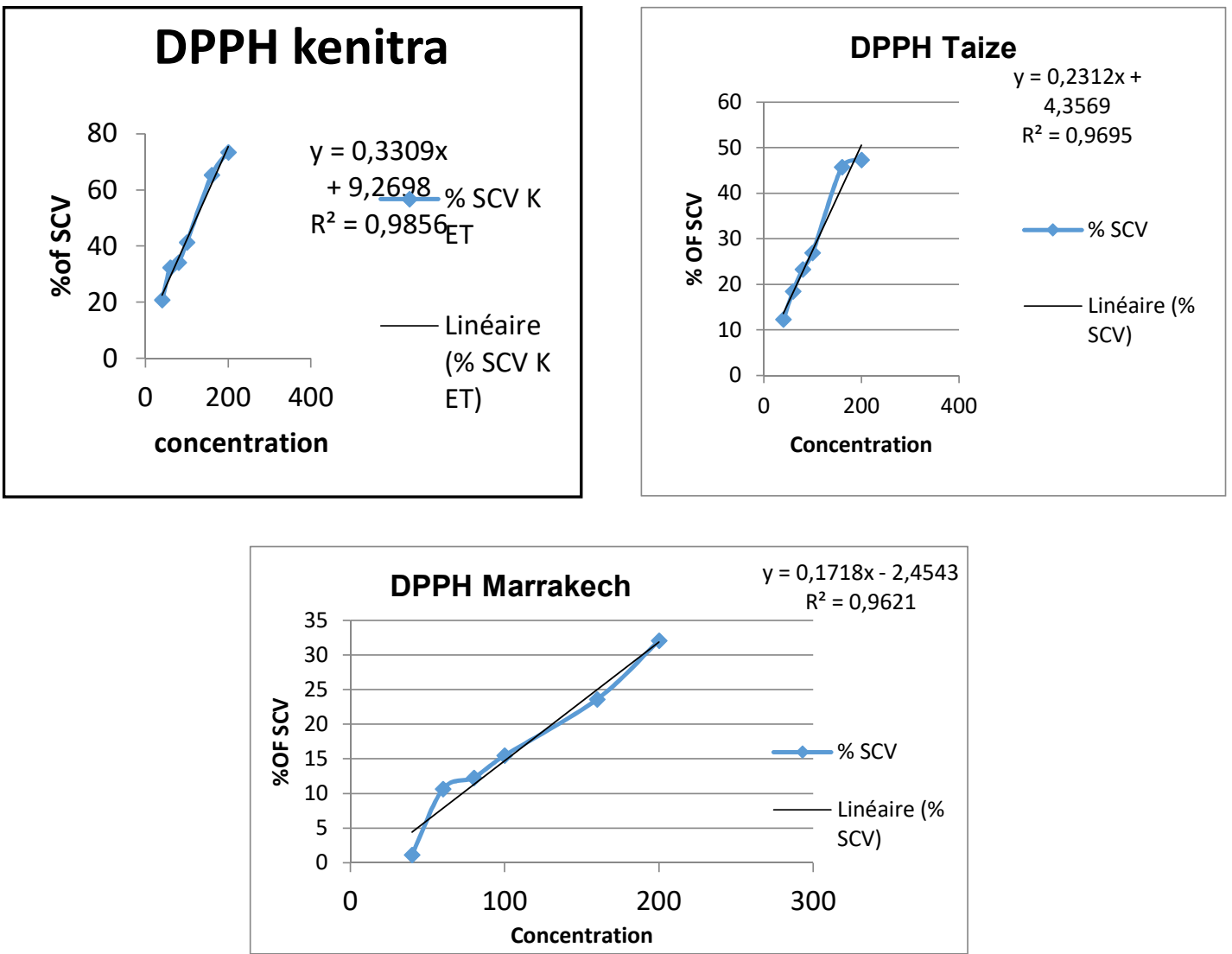

Fig. 3.The radical scavenging activity of ethanolic extract of the dried lemon peel of Marrakech, Kenitra and Taiz

Table 6.The relations between the total content of phenols and IC50 values of ethanolic extract of dried lemon peels of Marrakech, Kenitra andTaiz.

\begin{tabular}{|l|c|c|}
\hline $\begin{array}{l}\text { C.limon/ Extract } \\
\text { Ethanol }\end{array}$ & $\begin{array}{l}\text { TPC as } \\
\mathrm{ug} / \mathrm{ml} \mathrm{GAE}\end{array}$ & $\begin{array}{l}\text { IC50 } \\
\mu \mathrm{g} / \mathrm{mL}\end{array}$ \\
\hline Kenitera & 30.230 & 123.089 \\
\hline Marrakech & 26.346 & 197.418 \\
\hline Taize & 20.961 & 276.750 \\
\hline
\end{tabular}

Key: IC50: The half- maximal inhibitory concentration TPC: Total phenolic content 
Table 7. Adsorption parameters for C38 in $1 \mathrm{M}$ Hydrochloric acid of lemon peels in Kenitra and Taiz obtained from Langmuir adsorption isotherm

\begin{tabular}{lccc}
\hline extract & $K_{\text {ads }}(m L L-1)$ & $\mathbf{r}^{2}$ & $\Delta \mathbf{G}_{\text {ads }}$ \\
\hline Kenta & $\mathbf{0 , 9 5 5}$ & 0,993 & $-9,83$ \\
\hline Taiz & $\mathbf{0 , 8 8 7}$ & 0,996 & $-9,63$ \\
\hline
\end{tabular}

Key: $\Delta$ Gads: the standard free energy of adsorption

$\mathrm{R} 2$ : yield a straight line with a correlation coefficient,

$\operatorname{Kads}(m L L-1)$ : The equilibrium constant for the adsorption process

\subsection{Adsorption isotherm}

The adsorption parameters and Langmuir isotherm curve of C38 in 1M hydrochloric acid for the ethanolic extract of lemon peels in Kenitra and Taiz obtained from the adsorption isotherms according to Langmuir in Table 7 and Fig 4.

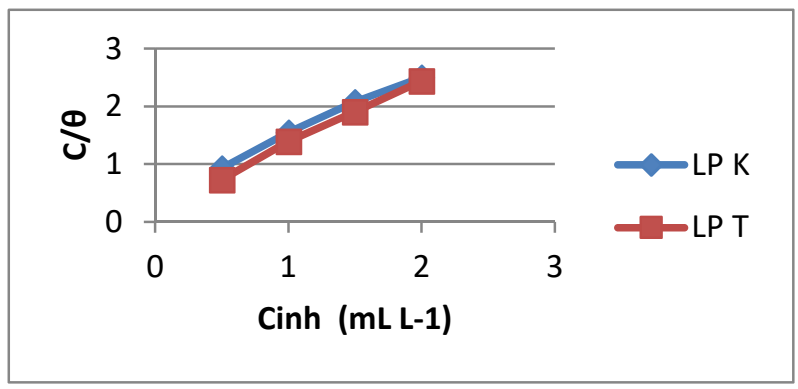

Fig.4.Langmuir isotherm curve of C38 in 1M Hydrochloric acid in the presence of the extract of lemon peels in Kenitra and Taiz.

Key: PLK: citrus lemon peels in Kenitra cities of Morocco, PLT: citrus lemon peels in Taiz of Yemen, $\mathrm{C}_{\text {inh }} \mathrm{mL} \mathrm{L-1:}$ the concentration of inhibitor

\subsection{Polarization curves} 9.

Their extrapolation parameters and inhibitory efficacy values presented of extracts as in Table 8,

Obtained Tafel curvelines in various concentrations are shown of extracts as in Fig 5, 6.

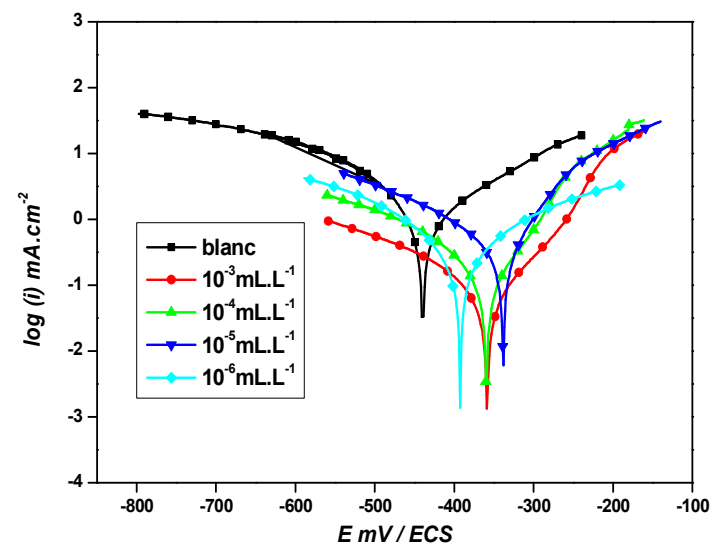


Fig. 5.Tafel curves of $\mathrm{C} 38$ in $1 \mathrm{M}$ Hydrochloric acid in the absence and presence of the extract of lemon peels Kenitra.

Table 8. Electrochemical factors for $\mathrm{C} 38$ in $1 \mathrm{M} \mathrm{HCl}$ in the absence and presence of the extract of lemon peels in Kenitra.

\begin{tabular}{|c|c|c|c|c|c|}
\hline $\begin{array}{c}C \text { inh } \\
(m L L-1)\end{array}$ & $\begin{array}{c}\text { Ecorr } \\
m v / S C E\end{array}$ & $\begin{array}{c}\text { Icorr } \\
\mu A / \operatorname{cm} 2\end{array}$ & $\begin{array}{c}\beta a \\
m V / d e c\end{array}$ & $\begin{array}{c}\beta c \\
m V / d e c\end{array}$ & $I E \%$ \\
\hline Blanc & $-442,823$ & 610,366 & 105 & 74.08 & \\
\hline 0,5 & $-374,706$ & 210,06 & 120.8 & 100 & 65,58 \\
\hline 1 & $-\mathbf{3 3 3}, \mathbf{8 8 7}$ & 113,438 & 63,4 & 140,2 & 84,36 \\
\hline 1,5 & $-354,779$ & 288,36 & 58,5 & 80,1 & 95,27 \\
\hline 2 & $-353,272$ & 114,64 & 54,3 & 67 & 98,12 \\
\hline
\end{tabular}

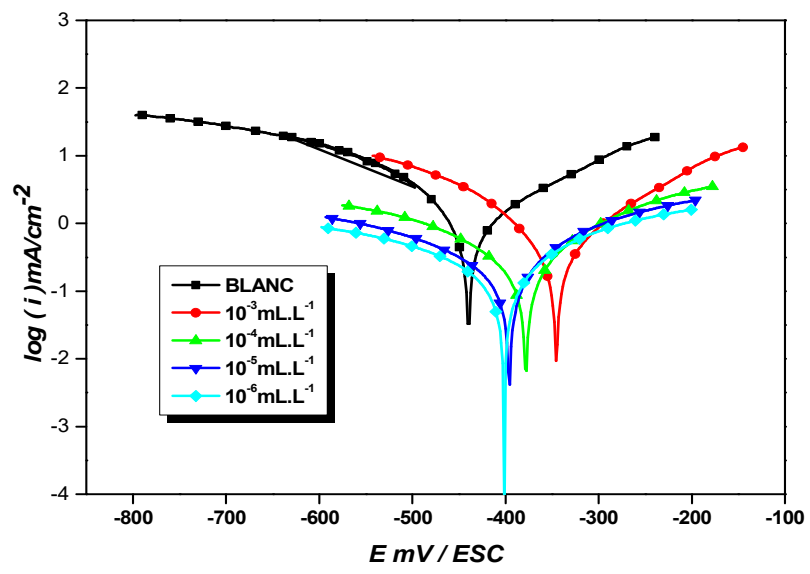

Fig.6.Tafel curves of $\mathrm{C} 38$ in $1 \mathrm{M} \mathrm{HCl}$ in the absence and presence of the extract lemon peels of Taize.

Table 9. Electrochemical factors of $\mathrm{C} 38$ in $1 \mathrm{M} \mathrm{HCl}$ in the absence and presence of the extract of lemon peel in Taize

\begin{tabular}{|c|c|c|c|c|c|}
\hline $\begin{array}{l}C_{\text {inh }} \\
(m L L-1)\end{array}$ & $\begin{array}{l}\text { Ecorr } \\
m v / S C E\end{array}$ & $\begin{array}{l}\text { Icorr } \\
\mu A / c m 2\end{array}$ & $\begin{array}{l}\beta a \\
m V / d e c\end{array}$ & $\begin{array}{l}\beta c \\
m V / d e c\end{array}$ & $\begin{array}{l}I E \\
\%\end{array}$ \\
\hline blank & $-442,82$ & 610,37 & 105,0 & 74,8 & \\
\hline 0,5 & $-405,03$ & 248,03 & 213,6 & 350,2 & 59,4 \\
\hline 1 & $-401,46$ & 199,29 & 151,3 & 292,2 & 67,3 \\
\hline 1,5 & $-349,74$ & 108,56 & 42,5 & 38,92 & 82,2 \\
\hline 2 & $-381,99$ & 92,46 & 64,3 & 82,8 & 84,8 \\
\hline
\end{tabular}

\subsection{Electrochemical impedance spectroscopy (EIS)}

Impedance curves which obtained in various concentrations with the absence and presence of extracts are shown as in Fig 5, 6. 
The Electrochemical parameters which obtained in various concentrations with the absence and presence of extractsare shown as in Table 10,11. To get a usable digital data, the electrical equivalent circuits are shown as in Fig.9.

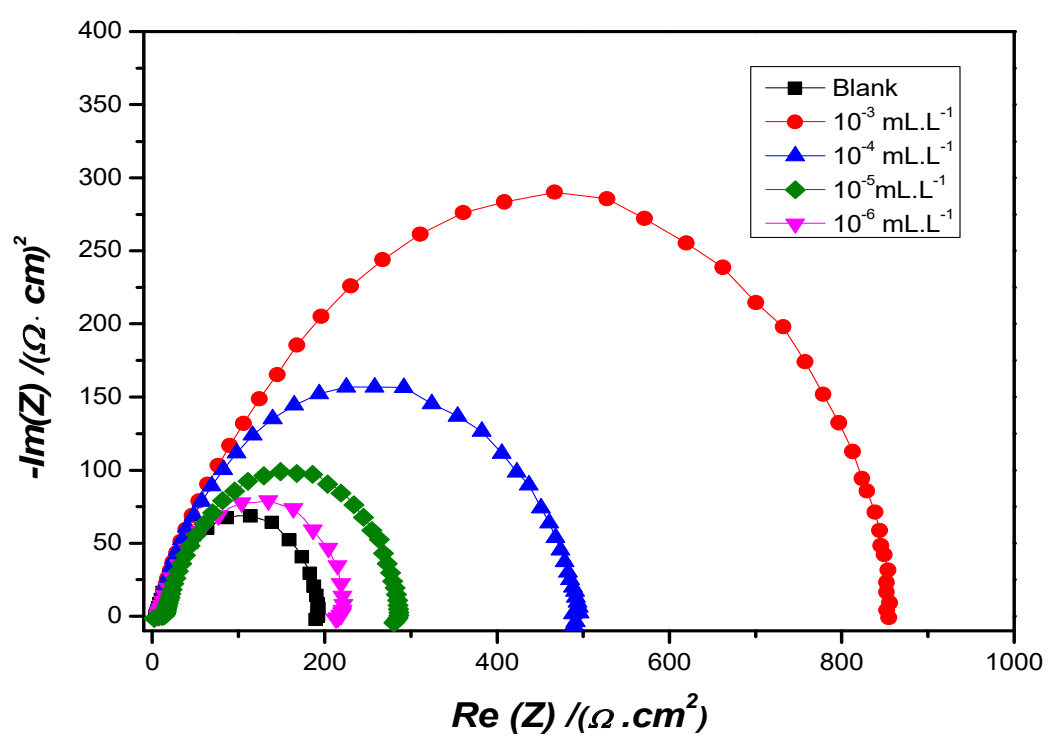

Fig.7.Impedance curves which obtained through $\mathrm{C} 38$ in $1 \mathrm{M} \mathrm{HCl}$ solution with the absence and presence of lemon peels in Kenitra.

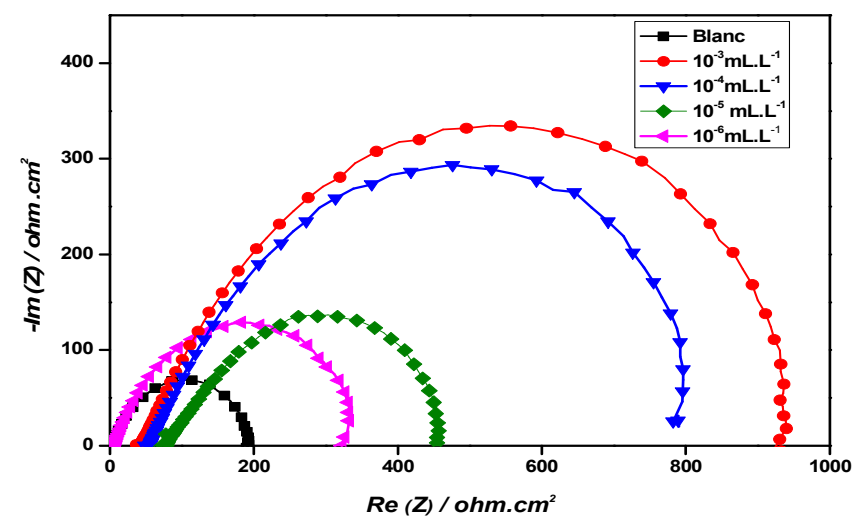

Fig.8. Impedance curves for $\mathrm{C} 38$ in $1 \mathrm{M} \mathrm{HCl}$ solution in the absence and presence of the extract of lemon peels in Taiz.

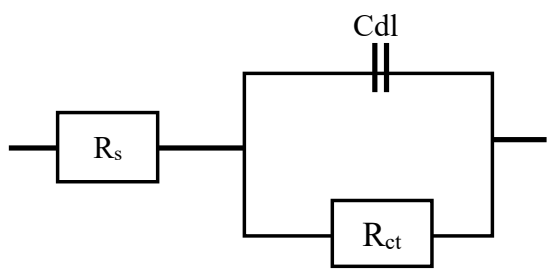

Fig .9.Equivalent circuit model used to fit experimental EIS. 
Tabl 10.Electrochemical factors for $\mathrm{C} 38$ in $1 \mathrm{M} \mathrm{HCl}$ in the absence and presence of the extract of lemon peels in Taiz

\begin{tabular}{|c|c|c|c|}
\hline $\begin{array}{l}\text { Cinh } \\
(m L L-1)\end{array}$ & $\begin{array}{l}\text { Rct } \\
\left(\boldsymbol{\Omega} . \mathrm{Cm}^{2}\right)\end{array}$ & $C d l$ & $I E \%$ \\
\hline \multicolumn{4}{|c|}{ Ethanolic extract Taize } \\
\hline Blanc & 172,4 & 5,87 & - \\
\hline 0,5 & 372,2 & 1,84 & 53,68 \\
\hline 1 & 485,5 & 1,45 & 64,49 \\
\hline 1,5 & 620,5 & 1,59 & 72,21 \\
\hline 2 & 862,2 & 1,02 & 80,00 \\
\hline
\end{tabular}

Tabl 11. Electrochemical parameters for $\mathrm{C}$-steel in $1 \mathrm{~mol} \mathrm{HCl}$ in the absence and presence of lemon peel in Kenitra.

\begin{tabular}{|c|c|c|c|}
\hline $\begin{array}{l}\text { Cinh } \\
(m L L-1)\end{array}$ & $\begin{array}{l}\text { Rct } \\
\left(\boldsymbol{\Omega} . \mathrm{cm}^{2}\right)\end{array}$ & $C d l$ & $I E \%$ \\
\hline & Ethanolic & & \\
\hline Blanc & 172,4 & 5,87 & - \\
\hline 0,5 & 549,5 & 3,08 & 68,63 \\
\hline 1 & 616,3 & 2,01 & 72,03 \\
\hline 1,5 & 812,8 & 2,81 & 78,79 \\
\hline 2 & 965,2 & 1,7 & 82,14 \\
\hline
\end{tabular}

Key: Rct: Charge transfer resistance, Cdl: double - layer capacitance, IE\%: inhibition efficiency

\section{Discussions}

It is clear from the obtained results in Table 1.The yield rate of essential oil in Kenitra was $0.42 \%$ higher than the yield in the Marrakech, which was $0.31 \%$. Moreover, the yield rate of extracted ethanolic in Kenitra was $(25.553 \%)$ higher than the yield in the Marrakech . It was sequentially $18.39 \%$ higher than the yield in the Taiz which was $(13.43 \%)$. The obtained results in this work showed less rate of the yield comparing with another study in the North East of Tunisia by $1.30 \%$, but they were a similar to the results which are introduced by Lota et al, where the yield was about $0.05 \%$ to $0.60 \%$ [24]. Therefore, the changes in these results were depended on the natural environment, extraction procedure, climate, distance, proximity to the sea, elevation, ecological conditions, mode of operation (drying - distillation method), harvest and ripening time [25], ecological conditions[26] and water shortage conditions [27].

It is clear from the obtained results in Table 3. The ethanolic extracts of the lemon peels are subjected to screening for their total polyphenols contents. The polyphenols content of ethanolic extract in Kenitra was $30.23 \mu \mathrm{g} / \mathrm{ml}$. It was relatively high comparing with the ethanolic extract in Marrakech and Taiz, which were 26.34 and $20.96 \mu \mathrm{g} / \mathrm{ml}$ respectively. Therefore, they can free radical scavenging using DPPH free radicals.

In Table $(5,6)$ and Fig $(3,4)$, the free radical removal activity evaluated by using of DPPH for ethanolic extract of dried lemon peels. The highest free radical removal activity values at $200 \mu \mathrm{g} / \mathrm{ml}$ concentrations were $73.47 \%, 47.36 \%$, and 32.09 . These values calculated the IC50 values at the same concentration were $123.089,197.418$ and $276.750 \mu \mathrm{g} / \mathrm{mL}$ in Kenitra, Marrakech and Taiz respectively. So, the extract containing a high amount of phenolic was showed high radical scavenging activity. When the antioxidant activity and TPC had been determined by plotting IC50 $(\mu \mathrm{g} / \mathrm{ml})$ against TPC $(\mathrm{mg} / \mathrm{g})$, it observed that, the increase of the phenolic of the ethanol extract in Kenitra and IC50 was $123.089 \mu \mathrm{g} / \mathrm{Ml}$ 
which is low comparing with the ethanolic extract in Marrakech and Taiz which were $197.418,276.750 \mu \mathrm{g} / \mathrm{mL}$ respectively.

Therefore, the phenolic compounds are responsible for DPPH free radical scavenging of the extracts. Table 7 indicates that the adsorption of inhibitors follows the Langmuir model as the correlation coefficient $(R 2)$ for both inhibitors was $0.99 \%$. Therefore, the experimental data gave an excellent curve fitting for this adsorption isotherm, and the negative value of the standard free energy of adsorption $\Delta G^{\circ}$ adsindicated the spontaneous adsorption process (physisorption).

Through Fig 6, 7 for the Tafel curve, we notice a decrease in the cathode and anode current. Therefore, this inhibition is from mixed-type.

In Table 8, we observe the polarization parameters when increasing inhibitor concentration at $2 \mathrm{~mL} \mathrm{L-1}$ and lower corrosion current density (Icorr) by $114.64 \mu \mathrm{A} / \mathrm{cm} 2$. The inhibition efficiency increased (IE \%) by $98.12 \%$ in Kenitra. For Taiz in Table 9, the inhibition efficiency was $84.85 \%$. It was less compared with inhibiting efficiency in Kenitra.

In Table 11, it is clear that Impedance parameters when there was increasing inhibitor concentration at (2 mL L-1), there is increasing Charge transfer resistance (Rct) to the value $862.2 \Omega . \mathrm{cm} 2$, whereas there is a lower double-layer capacitance $(\mathrm{Cdl})$ by 1.02 . Also, there is increasing in The inhibition efficiency IE \% to 82, $14 \%$ in Kenitra. For the obtained results in Taiz as in Table 10, the inhibition efficiency was $80,00 \%$, which was less than inhibiting efficiency in Kenitra.

This indicates to a decrease in the active surface area which caused by the adsorption of the inhibitors on the carbon steel surface and that the corrosion process became hindered as a result to a decrease in the local dielectric constant and increase the thickness of the electric double layer [28], which decreased the extent of dissolution reaction [29,30].

\section{Conclusion}

This study confirms the highest percentage of the yield, total polyphenol content, antioxidant activity, and the inhibition efficiency of the extracted ethanol of lemon peels in kenitra city and the lowest percentage of Marrakech and Taize cities. It is due to many factors that including the difference in climate, proximity to the sea and altitude, environment conditions.

The lemon fruit considered the most global produced with about six million metric tons. Its production in Morocco amounted to about 44,000 thousand metric tons. Therefore, one of the proposed recommendations in the future is to exploit lemon peels to extract their chemical compounds as a medicinal product and rid the environment of those peels in a friendly and purposeful manner.

\section{Acknowledgement}

I owe a unique sense of cordial gratitude to my supervisors, prof. Khedid Khadija, prof.Said IBN AHMED and research student Rahma ERAHIOUI who has quiet wisdom, good knowledge, infinite patience, sociable nature, valuable contribution and meticulous scrutiny of drafts always made this work achievable. Hearty thanks to all faculty members. I am deeply indebted to all my family members whom have a large green on me especially my father, my mother, and my brothers.

\section{References}

1. A. L.Demain, Applied microbiology and biotechnology, 52(1999).

2. A. K..Sarrmah, M. T. Meyer and A. B. Boxall, Chemosphere, 65(2006).

3. J.Wright, Comparative Political Studies, 43(2010).

4. T. Liu A. Stern, L.J. Roberts and J.D. Morrow, J Biomed Sci, 6(1999). 
5. Zunino, SJ. and D.H. Storms, Stephensen CBJ Nutr,137(2007).

6. X. Lv, S. Zhao, Z. Ning, H. Zeng, Y. Shu, Chemistry Central Journal., 9(2015).

7. R. Casquete, Innovative Food Science \& Emerging Technologies, 31(2015).

8. B.brand, Food SciTechnolInt, 28(1995).

9. V. Bonded, W. Brand-Williams, and C. Berset, Food SCIENCE AND TECHNOLOGY-ZURICH, 30(1997).

10. J. A. CSanchez-Moreno and F. Larrauri, Saura-Calixto, FoodAgri, 76(1998).

11. I. F. Benzie and J.J.Strain,Analytical biochemistry, vol. 239(1996) .

12. N. J. Miller and C. A. Rice-Evans,Food Chemistry, 60(1997).

13. R. Re. Pellegrini, A. Proteggente, A. Pannala, M. Yang, and C. Rice-Evans,Free radical biology and medicine, 26(1999) .

14. M. H. Hussin, M. J. Kassim, N. N. Razali, N. H. Dahon, and D. Nasshorudin, Arabian Journal of Chemistry, 9(2016).

15. N. O. Eddy,PortugaliaeElectrochimicaActa, 27(2009).

16. E. L. Vermeirssen, C. Dietschweiler, I. Werner, and M. Burkhardt,Water research, 123(2017).

17. P. B. Raja, S. Ghoreishiamiri, and M. Ismail, "Natural corrosion inhibitors for steel reinforcement in concrete - a review surface Review and Letters, 22(2015).

18. G. Trabanelli, C. Monticelli, and F. Zucchi, International Journal of Corrosion and Scale Inhibition, 4(2015).

19. A. Y. El-Etre, M. Abdallah, and Z. E. El-Tantawy, Corrosion science, 47(2005).

20. J.U. Ewansiha, SA.Garba, M.Galadima,SY. Daniyan, and MB. Busari ,Int J Res Stud Biosci, 4 (2020).

21. R.Adams, Identification of Essential Oil Components by Gas Chromatography/Quadrupole Mass Spectroscopy, Carol Stream, 16 (2005).

22. E. Lister, P.Wilson. Measurement of Total Phenolics and ABTS Assay for Antioxidant Activity (Personal Communication). Crop Research Institute Lincoln, New Zealand, (2001).

23. ES. Contreras-Guzman, F.C. Strong. Determination of tocopherols (Vitamin E) by reduction of cupric ion. JAOAC. 65(1982).

24. M.-L. Lota, D. de Rocca Serra, F. Tomi, and J. Casanova, Biochemical Systematics and Ecology, 29(2001).

25. M. Kelen and B. Tepe, Bioresource technology, 99(2008 Comparative Political Studies, 43(2010).

26. B. M. Smallfield, J. W. van Klink, N. B. Perry, and K. G. Dodds, Journal of Agricultural and Food Chemistry, 49(2001).

27. H. Bendaha ,Der Pharmacia Lettre, 8(2016).

28. E. McCafferty and N. Hackerman, Journal of the Electrochemical Society, 119(1972).

29. F. Bentiss, M. Traisnel, and M. Lagrenee, Corrosion science, 42(2000).

30. S. Muralidharan, K. L. N. Phani, S. Pitchumani, S. Ravichandran, and S. V. K. Iyer, Journal of the Electrochemical Society, 142(1995). 